\title{
Foaming properties of soy protein isolate hydrolysates
}

\author{
Luis Alberto Panizzolo ${ }^{1}$, María Cristina Añón ${ }^{2}$ \\ ${ }^{1}$ Departamento de Ciencia y Tecnología de Alimentos, Facultad de Química, Universidad de la República, Av. Gral, Flores 2124, 11800, \\ Montevideo, Uruguay \\ ${ }^{2}$ Centro de Investigación y Desarrollo en Criotecnología de Alimentos (CIDCA), CONICET, Facultad de Ciencias Exactas, Universidad \\ Nacional de La Plata Calle 47 y 116, 1900. La Plata. Argentina
}

\section{Email address:}

apanizzo@fq.edu.uy (L. A. Panizzolo)

\section{To cite this article:}

Luis Alberto Panizzolo, María Cristina Añón. Foaming Properties of Soy Protein Isolate Hydrolysates. Journal of Food and Nutrition Sciences. Vol. 3, No. 1, 2015, pp. 1-9. doi: 10.11648/j.jfns.20150301.11

\begin{abstract}
Tensoactive species obtained by papain hydrolysis of soy protein were characterized structurally and physicochemically, and their foam-forming and -stabilizing capacity studied. Protein structural changes upon reaction ending were correlated with functional and interfacial properties and with the behaviour thereof with varying hydrolysis degree. Two different means of halting hydrolysis $-\mathrm{pH}$ reduction $(\mathrm{pH}=2)$ and quick freezing $\left(-18{ }^{\circ} \mathrm{C}\right)$, respectively- were studied. Distinct structural changes and associated functional properties were found according to reaction ending conditions. No improvement of foaming properties was found for partially-hydrolyzed isolates subject to freezing at reaction ending - with respect to the starting unhydrolyzed soy protein isolate. In contrast, $\mathrm{pH}$ treatment as a means of halting hydrolysis led to a significant enhancement of the foaming properties of soybean protein hydrolysates consistently for all studied hydrolysis degrees $(0 \%$, $1.8 \%, 2.5 \%$ and $6 \%)$.
\end{abstract}

Keywords: Soy Protein, Enzymatic Hydrolysis, Foaming Properties

\section{Introduction}

Soy protein is a protein that is isolated from soya bean. Soya bean (Glycine max) is a species of legume family (Fabaceae) cultivated for its seeds. Soy protein is made from soybean meal that has been dehulled, defatted and processed into three kinds of high protein commercial products: soy flour, concentrates, and isolates. Soy protein finds a variety of applications in the food industry for its functional properties and his popularity has increased due to its use in health food products. In view of its high digestibility and balanced aminoacid composition, soy protein constitutes a major protein source capable of substituting meat and dairy proteins in the manufacture of food products. As little as $1 \%$ of the soy protein production is currently used in the human food industry for the improvement of textural properties; the rest being used in the manufacture of animal feeds [1]. Soy protein is used predominantly as a functional ingredient in view of its gelling, and foam- and emulsion-forming and stabilizing capacity [1]. However, poor foaming properties have been attributed to a highly compact structure of soybean protein -compared with protein from other sources- not liable to adsorption or unfolding at the interface in a way such that it prevents adequate formation of interfacial film [2].

A limited extent of proteolysis has been suggested to have a positive effect on the surface activity and the foaming and emulsifying properties of soy proteins [3]. Previous studies were focused on the modifications resulting from enzymatic hydrolysis of soy proteins using papain and on the relationship between the structural changes undergone during hydrolysis and the functional properties of modified proteins [4], [5]. Nonetheless, recent advances in analytical foam formation and stabilization methods may be used in furthering research on the dependence between surface functional properties and protein structure. In particular, further research on the improvement of functional properties of soy protein at $\mathrm{pH}$ above 4 has been suggested with a view to the inclusion of these proteins into suitable applications in food systems [1].

Here, a structural and physicochemical characterization was made of the products of partial papain hydrolysis of soy protein using two different means of halting the reaction. The effects of low-temperature and low-pH ending conditions were thus compared with a view to studying the suitability of hydrolyzed soy protein for food applications. The behaviour of interfacial and foaming properties was correlated with the 
structural changes undergone by the soy protein isolates during hydrolysis and according to means of reaction halting.

\section{Materials and Methods}

\subsection{Preparation of Soy Protein Isolates}

Soy protein isolates (SPI) were obtained from defatted soybean flour by solubilization in alkaline aqueous medium ( $\mathrm{pH}$ 8.0), followed by isoelectric precipitation ( $\mathrm{pH} 4.5$ ), precipitate dispersion in alkaline medium $(\mathrm{pH}$ 8.0) and drying by liofilization [6].

\subsection{Preparation of Soy Protein Hydrolysates}

SPIs (at a concentration of c.a. $30 \mathrm{mg} / \mathrm{ml}$ ) were incubated with papain solution $(0.2 \mathrm{mg} / \mathrm{ml})$ in a $4: 1$ (vol:vol) ratio under agitation in a thermostatized bath at $40^{\circ} \mathrm{C}$. SPIs had a protein content of $90.8 \pm 0.4 \mathrm{~g} / 100 \mathrm{~g}$, a water content of 3.50 $\pm 0.02 \mathrm{~g} / 100 \mathrm{~g}$ and a mineral ash content of $5.7 \pm 0.02 \mathrm{~g} / 100$ g. Papain purchased from Sigma contained 28 units $/ \mathrm{mg}$-with one enzyme unit hydrolyzing $1.0 \mu \mathrm{mol}$ of $\alpha$-N-benzoyl-Larginine ethyl ester (BAEE) per minute at $\mathrm{pH} 6.2$ at $25^{\circ} \mathrm{C}$. Substrate solutions or dispersions were prepared in $0.01 \mathrm{M}$ $\mathrm{Na}_{3} \mathrm{PO}_{3}$ buffer solution of $\mathrm{pH}$ 8.0. Different hydrolysis degrees $(0 \%, 1.8 \%, 2.5$ and $6.0 \%)$ were obtained according to different times of reaction. Hydrolysis was halted by means of: 1) $\mathrm{pH}$ reduction in the dispersion of soy protein isolate hydrolysates (SPIHs) to $\mathrm{pH} 2$ using $6 \mathrm{~N} \mathrm{HCl}(\mathrm{HpH})$; and 2) quick freezing of the SPIH dispersion in a bath with ice / $\mathrm{NaCl}$ cryogenic mixture at $-18{ }^{\circ} \mathrm{C}(\mathrm{HT})$. SPIHs thus obtained were subject to liofilization. SPIHs of equal hydrolysis degree were obtained from the same pool of SPIs for either means of reaction halting.

\subsection{Hydrolysis Degree Determinations}

Hydrolysis degrees (HDegs) were determined by determination of free amino groups by the trinitrobenzenesulphonic acid (TNBS) method as described by [7], following the modifications introduced by [8]. Determinations were made by triplicate measurements using a standard absorbance curve for l-leucine at $420 \mathrm{~nm}$.

\subsection{Hydrolysate Composition}

The protein content of SPIHs was determined by the method proposed by Lowry [9] using $100 \mu \mathrm{g} / \mathrm{ml}$ dispersions in $0.01 \mathrm{M} \mathrm{Na}_{3} \mathrm{PO}_{3}$ solution at $\mathrm{pH}$ 8.0. The water content was determined according to AOAC 14004 [10] and the ash content according to AOAC 31013 [10]. Determinations were based on triplicate measurements.

\subsection{Electrophoresis}

SDS electrophoresis was conducted on 7-15\% denaturating acrylamide gradient gel with $0.375 \mathrm{M}$ Tris- $\mathrm{HCl}$, $1 \%$ (w/v) SDS buffer solution of $\mathrm{pH}$ 8.8. Samples were conditioned with $0.125 \mathrm{M}$ Tris- $\mathrm{HCl}, 20 \%(\mathrm{v} / \mathrm{v})$ glycerol, $4 \%$ $(\mathrm{w} / \mathrm{v})$ SDS, $0.2 \%(\mathrm{w} / \mathrm{w})$ bromophenol blue buffer solution of
$\mathrm{pH}$ 6.8. The electrophoretic run buffer consisted of $0.025 \mathrm{M}$ Tris-HCl, $0.192 \mathrm{M}$ glycine, $0.1 \%(\mathrm{w} / \mathrm{v})$ SDS. The run was conducted at a constant voltage of $90 \mathrm{~V}$ applied to two 1.5 mm-thick gels. A Hoefer Scientific Instruments SE 640 electrophoresis unit was used. Protein molecular weight was estimated using a GIBCO BRL ${ }^{\circledR}$ 10064-012 molecular weight standard consisting of 12 genetically engineered proteins in the range of $10 \mathrm{kDa}$ to $120 \mathrm{kDa}$ separated at 10 $\mathrm{kDa}$ intervals in addition to another, $200 \mathrm{kDa}$ such protein. Determinations were based on duplicate measurements.

\subsection{Surface Hydrophobicity Determinations}

1-anilino-8-naphthalene sulphonate (ANS) was used as fluorescent probe [11]. Surface hydrophobicity determinations were based on SPIH dispersions in $0.1 \mathrm{M}$ $\mathrm{Na}_{3} \mathrm{PO}_{3}$ solution at $\mathrm{pH}$ 7.0. Fluorescence measurements were made on a Perkin Elmer 2000 spectrofluorometer, adjusting the relative fluorescence intensity to $80 \%$ of the full scale value using $15 \mu \mathrm{l}$ of $8 \mathrm{mM}$ ANS in $3 \mathrm{ml}$ absolute methanol and $364 \mathrm{~nm}$ and $484 \mathrm{~nm}$ excitation and emission wavelengths, respectively. Surface hydrophobicity was determined as the initial slope of the relative fluorescence intensity versus protein concentration plot, according to [12]. Determinations were based on duplicate measurements.

\subsection{Thermal Stability and Denaturation Degree Determinations by Differential Scanning Calorimetry}

Temperature, denaturation enthalpy and denaturation degree determinations were made on Polymer Laboratories PL-DSC equipment (Rheometric Scientific DSC 2, Ltd., Epsom, England). Aqueous dispersions of $20 \% \mathrm{w} / \mathrm{v}$ of the above described SPIHs in distilled water were used as samples. $20 \mathrm{mg}$ of each such sample were placed in hermetic aluminium pans for analysis. Runs were conducted at a heating rate of $10^{\circ} \mathrm{C} / \mathrm{min}$ over the temperature range of $25^{\circ} \mathrm{C}$ to $120^{\circ} \mathrm{C}$. A reference run was conducted using one sample previously subject to heating treatment as used during the analysis. For all samples, the dry-matter content was determined upon drying to constant weight -using perforated pans- in an oven at $105^{\circ} \mathrm{C}$.

The denaturation degree was calculated according to the equation: DDeg $=\left[\left(\Delta \mathrm{H}-\Delta \mathrm{H}_{\mathrm{T}}\right) / \Delta \mathrm{H}\right] \mathrm{x} 100$, DDeg being the denaturation degree, $\Delta \mathrm{H}$ the denaturation enthalpy of the unhydrolyzed starting protein, and $\Delta \mathrm{H}_{\mathrm{T}}$ the denaturation enthalpy of the protein modified by hydrolysis [13].

Runs were analyzed by means of Plus V5.41 Software. Determinations were based on duplicate measurements.

\subsection{Interfacial Tension Determinations}

Surface tension $(\sigma)$ measurements at the air/water interface were carried out on a Lauda TVT 2 drop volume tensiometer equipped with $2.5 \mathrm{ml}$ injection syringe. Determinations by the steady drop method were conducted for an initial number of six measuring cycles with three drops per cycle (6/3), using a drop formation rate in the range of 0.07-0.10 $\mathrm{s} / \mu \mathrm{l}$, followed by $9 / 3$ cycles/drops per cycle using a drop 
formation rate in the range of $0.10-0.80 \mathrm{~s} / \mu \mathrm{l}$. The pendant drop method, was used for $6 / 2$ cycles/drops per cycle in the 12 to $16.21 \mathrm{~s} / \mathrm{m}$ range of drop formation rate. Dissolutions at $\mathrm{pH} 8$ with a protein concentration of $1 \mathrm{mg} / \mathrm{ml}$ were obtained by dissolution of the protein hydrolysates in $0.1 \mathrm{M} \mathrm{Na}_{3} \mathrm{PO}_{3}$. The parameters used for analysis of here-described the assays, $\sigma_{\mathrm{e}}, \mathrm{k}_{\mathrm{a}}$ and $\mathrm{k}_{\mathrm{r}}$, are those used in the kinetic model developed by [14], where $\sigma_{\mathrm{e}}$ is the equilibrium surface tension, $\mathrm{k}_{\mathrm{a}}$ and $\mathrm{k}_{\mathrm{r}}$ first order rate constants of the protein adsorption and molecular rearrangement processes, respectively, at the air/water interface. Determinations were based on duplicate measurements of duplicate replicates.

\subsection{Foaming Capacity Analysis}

Foam formation and stabilization assays were conducted according to the conductimetric method developed by [15], following minor modification. Foam was generated by means of air bubbling at a flow rate of $100 \mathrm{ml} / \mathrm{min}$ through a G2type sintered glass plate until collection of a preset foam volume of $60 \mathrm{ml}$. The analysis was conducted using $10 \mathrm{ml}$ of dispersions of the hydrolysates in $0.1 \mathrm{M} \mathrm{Na}_{3} \mathrm{PO}_{3}$, at $\mathrm{pH} 8$, using protein concentrations of $1 \mathrm{mg} / \mathrm{ml}, 2 \mathrm{mg} / \mathrm{ml}$ and 5 $\mathrm{mg} / \mathrm{ml}$. Following the procedure described by [16], determinations of the initial liquid-to-foam transfer rate $\left(v_{i}\right)$ were based on initial slope analysis of the liquid volume incorporated in the foam $\left(\mathrm{V}_{\mathrm{LF}}\right)$ vs. time plot. The maximum value of liquid volume in the foam $\left(\mathrm{V}_{\max }\right)$ was also determined. The destabilization kinetics was analysed based on the parameters $\mathrm{k}_{\mathrm{g}}, \mathrm{V}_{\mathrm{g}}, \mathrm{k}_{\mathrm{d}}$ and $\mathrm{V}_{\mathrm{d}}$ resulting from application of the kinetic model developed by [17], where $\mathrm{k}_{\mathrm{g}}, \mathrm{V}_{\mathrm{g}}, \mathrm{k}_{\mathrm{d}}$ and $\mathrm{V}_{\mathrm{d}}$ are the rate constants and the maximum liquid volumes in the foam associated with gravitational drainage and gas diffusion or disproportionation processes, respectively, the latter also known as Ostwald's ripening. Determinations were based on triplicate measurements of duplicate replicates.

\subsection{Statistical Analysis}

The fixed-effects model of analysis of variance (ANOVA) was used for statistical treatment of data, with $\alpha=0.05$; followed by the comparison of mean values by the least significant differences (LSD) test, with $\alpha=0.05$, using Statgraphics plus 7.0 software.

\section{Results and Discussion}

\subsection{SPIH Composition}

HTs had a protein content in the range of 81.8 to 86.6 $\mathrm{g} / 100 \mathrm{~g}$, a water content between 12.10 and $13.20 \mathrm{~g} / 100 \mathrm{~g}$, and an ash content between 3.07 and $5.98 \mathrm{~g} / 100 \mathrm{~g}$ while $\mathrm{HpHs}$ had a slightly lower protein content, in the range of 79.1 to $80.4 \mathrm{~g} / 100 \mathrm{~g}$, a water content between 11.87 and $13.56 \mathrm{~g} / 100 \mathrm{~g}$ and an ash content between 6.03 and 9.08 $\mathrm{g} / 100 \mathrm{~g}$. Except for the ash content of $\mathrm{HpHs}$, the above contents are in agreement with the expected values considering the starting soybean flour (protein: $51.5 \pm 0.3$ $\mathrm{g} / 100 \mathrm{~g}$; water: $6.89 \pm 0.03 \mathrm{~g} / 100 \mathrm{~g}$; ash: $6.20 \pm 0.03 \mathrm{~g} / 100 \mathrm{~g}$ ) and the soy protein isolate (protein: $78.6 \pm 0.3 \mathrm{~g} / 100 \mathrm{~g}$; water: $10.09 \pm 0.05 \mathrm{~g} / 100 \mathrm{~g}$; ash: $4.53 \pm 0.02 \mathrm{~g} / 100 \mathrm{~g}$ ). The ash content of $\mathrm{HpHs}$ was higher than that of the starting material, on account of $\mathrm{HCl}$ additions used for halting the reaction.

\subsection{Structural Characterization of SPIHs}

\subsubsection{Polypeptide Composition}

Polypeptides characteristic of $\beta$-conglycinin and glycinin were found by SDS-PAGE electrophoresis analysis of SPI control samples (HDeg 0\%) and SPIH samples of low hydrolysis degree (HDeg 1.8\%). For both HTs and HpHs, an increased HDeg $(2.5 \%$ and $6.0 \%)$ led to the disappearance of the $\alpha$ and $\alpha$ ' bands of $\beta$-conglycinin and to a slight reduction of polypeptide A of glycinin (data not shown). In [18] it was reported that the action of papain on soybean protein isolates was initiated on $\beta$-conglycinin, followed by glycinin; the subunits of the former being hydrolyzed to a larger extent than the AB subunits of glycinin. Such results are in accordance with the above reported disappearance of the $\alpha$ and $\alpha$ bands in SPIHs of high HDeg (2.5\% and 6.0\%).

\subsubsection{Analysis of Thermal Properties}

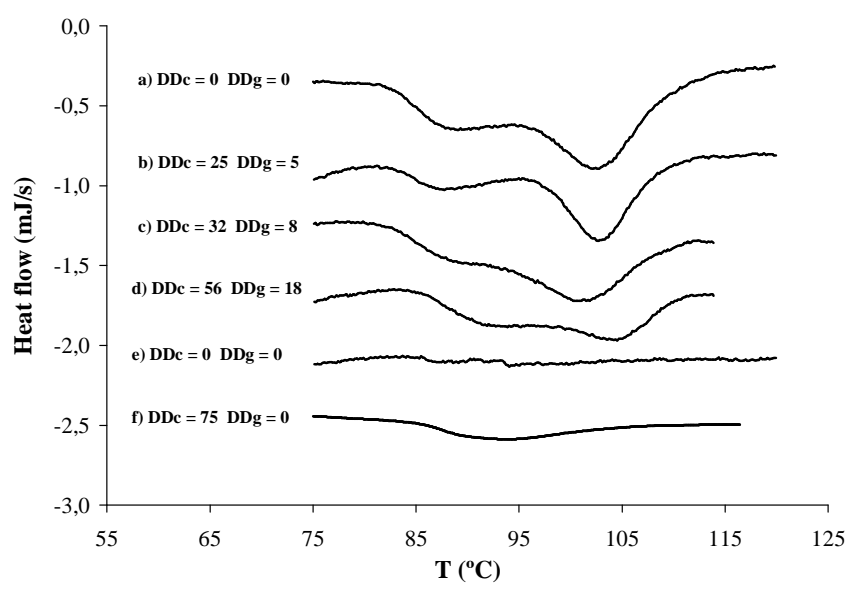

Figure 1. DSC thermograms of HT HDeg $O(a), 1.8(b), 2.5(c)$ and $6.0 \%(d)$, $\mathrm{HpH}$ at $\mathrm{pH} 2(e)$ and previously neutralized $\mathrm{HpH}(f)$. The first peak corresponds to $\beta$-conglycinin and the second one to glycinin. $\beta$-conglycinin $(D D c)$ and glycinin $(D D g)$ are expressed as percent fractions in all cases.

Figure 1 shows the thermograms of the analyzed hydrolysates. HTs ( $\mathrm{pH}$ 8.0) showed two endotherms associated with the denaturation of $\beta$-conglycinin and glycinin, respectively [19]. HTs of HDeg 6\% showed an increase in maximum peak temperature (from $89^{\circ} \mathrm{C}$ to $92{ }^{\circ} \mathrm{C}$ and from $102{ }^{\circ} \mathrm{C}$ to $104{ }^{\circ} \mathrm{C}$ ) and a lesser extent of differentiation between both endotherms. Figure 1 shows, for HTs, an increase in DDeg with increasing HDeg, the effect on $\beta$-conglycinin being greater than on glycinin, consistent with the above reported results of electrophoresis assays. This suggests that a larger proportion of glycinin molecules may either retain or not show major disarrangement in their protein structure as a result of proteolysis.

$\mathrm{HpH}$ thermograms, shown in Figure 1, did not show the 
endotherms corresponding to the denaturation of glycinin and $\beta$-conglycinin as a result of acid treatment used for halting the hydrolysis reaction. Similar results on the partial hydrolysis of $\beta$-conglycinin were previously reported [16], [20]. A partial reversal of the effect of acid treatment resulted from neutralization prior to thermal treatment of $\mathrm{HpHs}$, leading to a DDeg of c.a. $75 \%$ consistent for all analyzed samples (see Figure 1).

\subsubsection{Surface Hydrophobicity}

$\mathrm{HpHs}$ were found to have hydrophobicity (Ho) nearly twice as high as that of HTs $(\mathrm{HpH}$ HDeg 0\% Ho = $264 \pm 2$ and HT HDeg $0 \% \mathrm{Ho}=106 \pm 2$ ). In the range of low HDeg values, an increase in $\mathrm{HDeg}$ (to $1.8 \%$ for $\mathrm{HpHs}$ and to $1.8 \%$ and $2.5 \%$ for HTs) led to a significant increase in Ho (to 268 \pm 2 and to $126 \pm 2$ and $112 \pm 2$, respectively) whereas an even higher HDeg $(6.0 \%)$ led to a reduction in Ho to values nearly as low as those of the unhydrolyzed isolates $(207 \pm 2$ and $85 \pm 2$, respectively). Protein dissociation and unfolding resulting from treatment at $\mathrm{pH} 2$ led to increased exposure of sterically hindered hydrophobic zones of the unhydrolyzed proteins, with the resulting increase in surface hydrophobicity. Likewise, the unfolding of the protein structure resulting from hydrolysis further led to an increase in Ho. The increase in $\mathrm{Ho}$ as the reaction progressed may be attributed to the maintenance of major hydrophobic zones, such as polypeptide B of glycinin. In addition, the loss of hydrophilic peptides at the protein surface may also have led to an increase in hydrophobicity [21].

\subsection{SPIHs Used for Surface Tension Modification}

The parameters resulting from the model proposed by [14] were used for analysis of surface tension modification.

Table 1 shows the values of equilibrium surface tension $\left(\sigma_{\mathrm{e}}\right)$ and the protein adsorption and rearrangement first order rate constants at the air/water interface $\left(\mathrm{k}_{\mathrm{a}}\right.$ and $\mathrm{k}_{\mathrm{r}}$, respectively) for the assayed solutions.

Table 1. Surface tension variations in SPIHs [protein] $=1.0 \mathrm{mg} / \mathrm{ml}, \mathrm{pH}=$ 8.0 and $[\mathrm{NaCl}]=0 \mathrm{M}$

\begin{tabular}{llll}
\hline SPIH & $\mathbf{k}_{\mathrm{a}} \mathbf{\times 1 0}\left(\mathbf{s}^{\mathbf{- 1}}\right)$ & $\mathbf{k}_{\mathbf{r}} \mathbf{\times 1 \mathbf { 1 0 } ^ { 2 }}\left(\mathbf{s}^{-\mathbf{1}}\right)$ & $\boldsymbol{\sigma}_{\mathrm{e}}(\mathbf{m N} \mathbf{\mathbf { m }})$ \\
\hline HT HDeg 0\% & $1.4 \pm 0.1^{\mathrm{a}}$ & $0.77 \pm 0.09^{\mathrm{b}}$ & $52 \pm 1^{\mathrm{a}}$ \\
HT HDeg 1.8\% & $1.5 \pm 0.1^{\mathrm{a}}$ & $0.85 \pm 0.08^{\mathrm{b}}$ & $52 \pm 1^{\mathrm{a}}$ \\
HT HDeg 2.5\% & $1.4 \pm 0.1^{\mathrm{a}}$ & $0.80 \pm 0.08^{\mathrm{b}}$ & $53 \pm 1^{\mathrm{a}}$ \\
HT HDeg 6.0\% & $1.4 \pm 0.1^{\mathrm{a}}$ & $0.61 \pm 0.09^{\mathrm{c}}$ & $56 \pm 1^{\mathrm{b}}$ \\
HpH HDeg 0\% & $1.6 \pm 0.3^{\mathrm{a}}$ & $1.3 \pm 0.2^{\mathrm{a}}$ & $50 \pm 2^{\mathrm{a}}$ \\
HpH HDeg 1.8\% & $1.6 \pm 0.3^{\mathrm{a}}$ & $1.8 \pm 0.2^{\mathrm{a}}$ & $53 \pm 2^{\mathrm{a}}$ \\
HpH HDeg 2.5\% & $2.0 \pm 0.3^{\mathrm{a}}$ & $1.7 \pm 0.2^{\mathrm{a}}$ & $51 \pm 2^{\mathrm{a}}$ \\
HpH HDeg 6.0\% & $1.4 \pm 0.3^{\mathrm{a}}$ & $1.2 \pm 0.2^{\mathrm{a}}$ & $51 \pm 2^{\mathrm{a}}$ \\
\hline
\end{tabular}

Mean values of triplicate measurements are shown

Mean values identified by the same letter do not differ significantly ( $\alpha=$ $0.05)$

No significant differences were found in $\mathrm{k}_{\mathrm{a}}$ values for the treatments used to halt the reaction halting or for HDeg. $k_{r}$ differed in significant amounts for either type of ending treatment; the values for $\mathrm{HpH}$ being higher than for HT. The
HDeg affected $k_{r}$ only in the case of HTs, HDegs of $0 \%$, $1.8 \%$ and $2.5 \%$ leading to higher values than for HDeg $6 \%$. Likewise, no significant differences were found for $\sigma_{\mathrm{e}}$ according to ending treatment or HDeg, except for HT of HDeg 6\% with a significantly higher $\sigma_{\mathrm{e}}$ value than for the other HTs $(0 \%, 1.8 \%$ and $2.5 \%)$.

Above results showed that differences in the kinetics of surface tension modification found for $\mathrm{HT}$ and $\mathrm{HpH}$ are not to be ascribed to different equilibrium surface tension values for either type of hydrolysate, but, rather, to the rate of variation thereof (Figure 2). Such difference is reflected in the $\mathrm{k}_{\mathrm{r}}$ value, meaning that differences may lie only on a different protein rearrangement capacity at the interface. Higher $\mathrm{k}_{\mathrm{r}}$ values found for $\mathrm{HpH}$ may be attributed to a higher Ho and a lower molecular size of constituent polypeptides in view of the predominance of the $3 \mathrm{~S}$ form of glycinin at acid $\mathrm{pH}$ [22], leading to a greater ease of rearrangement at the interface. The above is consistent with results reported by [23] on the ease and high rate of unfolding and rearrangement of $3 \mathrm{~S}$ glycinin at the interface on account of a higher flexibility resulting from electrostatic repulsion forces within the molecule.

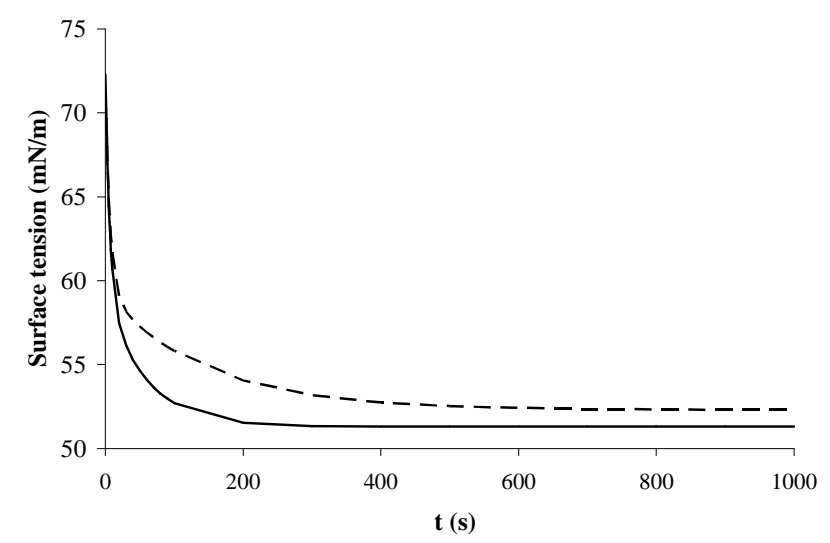

Figure 2. Surface tension vs. time plots showing the behaviour of HT (--) and $\mathrm{HpH}(-)$

In [11] it was reported that $\beta$-conglycinin is the protein fraction with the greatest interfacial surface reduction capacity. As shown in Table 1 HT of HDeg 6\% showed the lowest $k_{r}$ value, a fact which may be attributed to the reduction in size and the loss of globular structure of $\beta$ conglycinin as a result of hydrolysis. Although such loss of structure was found consistently for all $\mathrm{HpHs}$, a different behaviour from that of HTs was found. The fact that glycinin in $\mathrm{HpHs}-$ i.e. receiving $\mathrm{pH} 2$ treatment- is dissociated, less affected by proteolysis and has greater flexibility may account for the invariance in the $\mathrm{k}_{\mathrm{r}}$ value found for $\mathrm{HpH}$ HDeg $6 \%$ where the effect of the treatment used for hydrolysis halting was greater than that of the HDeg attained by reaction.

\subsection{Foamability}

The effects of the different variables used in the study on the initial liquid-to-foam transfer rate $\left(v_{i}\right)$ and the maximum 
liquid volume incorporated in the foam phase $\left(\mathrm{V}_{\max }\right)$ are shown in Table 2.

Table 2. $v_{i}$ and $V_{\max }$ values in foams formed using dissolutions of different SPIHs at different protein concentrations, at $p H 8.0$

\begin{tabular}{|c|c|c|c|c|c|c|}
\hline \multirow{2}{*}{ SPIH } & \multicolumn{2}{|c|}{ [protein]: $1.0 \mathrm{mg} / \mathrm{ml}$} & \multicolumn{2}{|c|}{ [protein]: $2.0 \mathrm{mg} / \mathrm{ml}$} & \multicolumn{2}{|c|}{ [protein]: $5.0 \mathrm{mg} / \mathrm{ml}$} \\
\hline & $v_{i}(\mathrm{ml} / \mathbf{s})$ & $\mathbf{V}_{\max }(\mathbf{m l})$ & $v_{i}(\mathrm{ml} / \mathbf{s})$ & $\mathbf{V}_{\max }(\mathbf{m l})$ & $v_{i}(\mathrm{ml} / \mathbf{s})$ & $\mathbf{V}_{\max }(\mathbf{m l})$ \\
\hline HT HDeg $0 \%$ & $0.18 \pm 0.02^{b}$ & $4.8 \pm 0.3^{b}$ & $0.23 \pm 0.02^{\mathrm{c}}$ & $6.5 \pm 0.3^{d}$ & $0.23 \pm 0.0^{c}$ & $7.4 \pm 0.3^{\mathrm{a}}$ \\
\hline HT HDeg $1.8 \%$ & $0.16 \pm 0.02^{\mathrm{b}}$ & $4.7 \pm 0.3^{\mathrm{b}}$ & $0.22 \pm 0.02^{\mathrm{c}}$ & $6.6 \pm 0.3^{d}$ & $0.25 \pm 0.02^{c}$ & $7.4 \pm 0.3^{\mathrm{a}}$ \\
\hline HT HDeg $2.5 \%$ & $0.17 \pm 0.02^{\mathrm{b}}$ & $4.7 \pm 0.3^{b}$ & $0.24 \pm 0.03^{c}$ & $6.7 \pm 0.3^{\mathrm{d}}$ & $0.28 \pm 0.04^{\text {a.c }}$ & $7.5 \pm 0.3^{\mathrm{a}}$ \\
\hline HT HDeg 6.0\% & $0.16 \pm 0.02^{b}$ & $3.6 \pm 0.4^{\mathrm{c}}$ & $0.17 \pm 0.04^{b}$ & $4.5 \pm 0.4^{\mathrm{b}}$ & $0.23 \pm 0.02^{c}$ & $6.9 \pm 0.4^{\text {a.d }}$ \\
\hline HpH HDeg 0\% & $0.26 \pm 0.02^{\mathrm{a}}$ & $7.6 \pm 0.3^{\mathrm{a}}$ & $0.27 \pm 0.01^{\mathrm{a}}$ & $7.4 \pm 0.3^{\mathrm{a}}$ & $0.30 \pm 0.03^{\mathrm{a}}$ & $7.7 \pm 0.3^{\mathrm{a}}$ \\
\hline HpH HDeg $1.8 \%$ & $0.30 \pm 0.02^{\mathrm{a}}$ & $7.8 \pm 0.3^{\mathrm{a}}$ & $0.28 \pm 0.02^{\mathrm{a}}$ & $7.6 \pm 0.3^{\mathrm{a}}$ & $0.29 \pm 0.03^{\mathrm{a}}$ & $8.1 \pm 0.3^{\mathrm{a}}$ \\
\hline HpH HDeg $2.5 \%$ & $0.30 \pm 0.02^{\mathrm{a}}$ & $7.8 \pm 0.3^{\mathrm{a}}$ & $0.32 \pm 0.02^{\mathrm{a}}$ & $8.0 \pm 0.2^{\mathrm{a}}$ & $0.36 \pm 0.03^{\mathrm{a}}$ & $8.2 \pm 0.3^{\mathrm{a}}$ \\
\hline HpH HDeg $6.0 \%$ & $0.26 \pm 0.02^{\mathrm{a}}$ & $7.1 \pm 0.3^{\mathrm{a}}$ & $0.28 \pm 0.03^{\mathrm{a}}$ & $7.7 \pm 0.3^{\mathrm{a}}$ & $0.30 \pm 0.03^{\mathrm{a}}$ & $7.9 \pm 0.3^{\mathrm{a}}$ \\
\hline
\end{tabular}

Mean values of triplicate measurements are shown

Mean values identified by the same letter $\mathrm{d}$

o not differ significantly $(\alpha=0.05)$

$v_{i}$ and $\mathrm{V}_{\max }$ values found for $\mathrm{HpH}$ foams were significantly higher than for HT foams. The HDeg affected $\mathrm{V}_{\max }$ significantly only for HT of HDeg 6\%, leading to a significantly lower value than for the rest of the analyzed samples $(0 \%, 1.8 \%$ and $2.5 \%)$ (Table 2). For HT foams, both $v_{i}$ and $\mathrm{V}_{\text {max }}$ increased with increasing protein concentration in the aqueous dissolution used for foaming assays. The effect of protein concentration on $\mathrm{V}_{\max }$, led to a lesser extent of variation of the latter between $\mathrm{HT}$ and $\mathrm{HpH}$ foams.

The liquid volume drained by a foam is affected by the bubble size according to Laplace's Law and by a reduction in surface tension, in turn leading to a lower pressure difference between bubbles. The $\Delta \mathrm{P}$ ratio for foam preparations using different protein solutions, assuming equal values of curvature radii, may be expressed as follows:

$$
\Delta \mathrm{P}_{1} / \Delta \mathrm{P}_{2}=\sigma_{1} / \sigma_{2}
$$

The maximum difference between $\sigma$ values found for HT and $\mathrm{HpH}$ preparations, during the kinetics of surface tension reduction, was that between $58 \mathrm{mN} / \mathrm{m}$ and $55 \mathrm{mN} / \mathrm{m}$ respectively -i.e. the maximum $\Delta \mathrm{P}$ between $\mathrm{HT}$ and $\mathrm{HpH}$ bubbles being $58 / 55=1.05 . \Delta \mathrm{P}$ differences, and hence differences in $v_{i}$ and $\mathrm{V}_{\max }$ values between HTs and HpHs, may clearly not be accounted for in terms of $\sigma$ values. A higher rate of incorporation of liquid into the foam phase may be associated with a greater resistance of $\mathrm{HpH}$ foams against incipient destabilization processes such as film rupture, Ostwald's ripening and gravitational liquid drainage. The above may also account for the higher $\mathrm{V}_{\max }$ values found for $\mathrm{HpH}$ foams, as previously mentioned.

According to [23], whereas both $3 \mathrm{~S}$ and $11 \mathrm{~S}$ glycinin may form cross-linkage at the air/water interface, the latter is less rigid on account of a less compact structure. For proteins previously denatured by the effect of acid $\mathrm{pH}$, glycinin occurring predominantly in the $3 \mathrm{~S}$ form- appears to have a greater ease and rate of rearrangement at the interface, in addition to the capacity of forming physical and covalent intermolecular interactions within the interfacial film. Hence, the film formed by $\mathrm{HpH}$ proteins is expected to show a higher resistance to destabilizing processes.

In the case of HT of HDeg 6\%, having a higher concentration of small-molecular-sized peptides adversely affecting foam stability [24], the above behaviour did not favour the formation of a cohesive film resistant to rupture and Ostwald's ripening. Acid treatment -leading to dissociation, denaturation and unfolding of $\mathrm{HpH}$ proteinsoffset the effect of hydrolysis, resulting in a similar interfacial behaviour of $\mathrm{HpH}$ of HDeg $6 \%$ to that found for the rest of HpHs.

The increase in protein concentration may lead to a higher lamellar viscosity and the formation of a cohesive film composed of several layers of protein molecules at the interface, according to [25]. Such effects would result in a greater film resistance against rupture and Ostwald's ripening. Higher $v_{i}$ and $\mathrm{V}_{\max }$ values may thus have resulted from an increase in protein concentration. The effect of protein concentration was less significant for $\mathrm{HpH}$ foams (Table 2). The above may be explained in terms of an improved interfacial behaviour associated with the stabilization of the film layer; while the improvement derived from an increase in protein concentration appears to have reached an optimal level at a value of $1 \mathrm{mg} / \mathrm{ml}$.

\subsection{Foam Stability}

Assays of foam stability were based on the rate constants of liquid drainage in the foam. The effects of the different variables studied on the values of drainage and gravitational rate constants, $\mathrm{k}_{\mathrm{d}}$ and $\mathrm{k}_{\mathrm{g}}$ respectively, are shown in Table 3 .

\subsubsection{Gravitational Drainage}

$\mathrm{k}_{\mathrm{g}}$ values of $\mathrm{HpH}$ foams with a protein concentration of 1 $\mathrm{mg} / \mathrm{ml}$ were significantly lower than for HT foams. With increasing protein concentration, differences between foams of both types of hydrolysate were reduced to insignificant values above at protein concentrations above $5 \mathrm{mg} / \mathrm{ml}$. HT foams of HDeg $6 \%$ showed a significantly higher $\mathrm{k}_{\mathrm{g}}$ value than for the rest of HTs $(0 \%, 1.8 \%$ and 2.5\%) (Table 3); whereas the HDeg did not have a significant effect on $\mathrm{k}_{\mathrm{g}}$ in 
$\mathrm{HpH}$ foams (Table 3). In HT foams, $\mathrm{k}_{\mathrm{g}}$ decreased significantly with increasing protein concentration (Table 3 ).

Much research has been reported on an inverse relation between foamability and stabilizing properties of proteins [26], [27], [28], [29], [25], [30], [31]. The results reported here are in disagreement with a generalization of the above statement as such, since both a greater foamability as well as stabilizing properties were found for $\mathrm{HpH}$ foams, consistently with results also reported by [32] and [16].

As foam stabilizing mechanisms occur during the stage of foam formation [33], the proteins that account for the good foamability of a solution may also render it more stable. In [1] there is reported on the rapid formation of a thin rigid protein film -i.e. which may be considered as a gel layer- following the adsorption of $3 \mathrm{~S}$ glycinin under appropriate occurrence conditions at the interface. $\mathrm{HpH}$ proteins therefore appear to form a gel-like protein layer leading to foam of a higher stability of a foam. Based on findings reported by [23], while both $3 \mathrm{~S}$ and $11 \mathrm{~S}$ glycinin have cross-linking capacity at the interface, the latter appears as less rigid in view of a greater degree of compaction, which may account for the fact that HT foams were found to retain a smaller amount of water in the lamella, consistent with a higher $\mathrm{k}_{\mathrm{g}}$ value found for foams of this type of hydrolysate.

The gel forming capacity was found to decrease with decreasing molecular size. For HDeg of $6 \%$, where the number of short-chain peptides was found to be greater than for the rest of the studied HDegs, the capacity of forming a gel-like film at the interface appears to have been reduced. The occurrence of low-molecular peptides may also have contributed to a lesser degree of resistance against the drainage process in foams of highly hydrolyzed protein.
Nonetheless, the effect of hydrolysis was offset by that of a high DDeg consistently for all $\mathrm{HpHs}$-where glycinin was found under $\mathrm{AB}$ subunits- with the result that no significant variation of stabilizing properties against liquid drainage was found among foams of this type of hydrolysate.

As discussed above in reference to the foam formation capacity, an increase in protein concentration led to a higher viscosity of the lamella and may contribute to the formation a thicker and more cohesive film at the interface comprised of various layers of protein molecules [26], [34], [27], [29], [26]. Further, a higher protein concentration may result in a higher extent of interaction with water molecules, thus retarding the drainage process. Protein concentration did not have a significant effect on stability for $\mathrm{HpH}$ foams above an optimal protein concentration value found at $1 \mathrm{mg} / \mathrm{ml}$, as discussed above.

The amount of drained liquid is strongly influenced by the size of bubbles, as discussed above, the former decreasing with increasing bubble radius. Despite the smaller bubble radius of $\mathrm{HpH}$ foams, they were found to have a smaller rate of liquid drainage, leading to an enhancement of the stabilizing properties of these foams compared with those of HT foams.

\subsubsection{Liquid Drainage Due to Ostwald's Ripening}

HT foams were found to have a higher stability to Ostwald's ripening, consistent with the estimated $k_{d}$ values amounting to several orders of magnitude below the values found for $\mathrm{HpHs}$ (Table 3). $\mathrm{k}_{\mathrm{d}}$ values for $\mathrm{HpH}$ foams were found to decrease significantly with increasing protein concentration (Table 3).

Table 3. $k_{g}$ and $k_{d}$ values in foams prepared using SPIH solutions at pH 8.0 for different protein and NaCl concentrations.

\begin{tabular}{|c|c|c|c|c|c|c|}
\hline \multirow{2}{*}{ SPIH } & \multicolumn{2}{|c|}{ [protein]: $1.0 \mathrm{mg} / \mathrm{ml}$} & \multicolumn{2}{|c|}{ [protein]: $2.0 \mathrm{mg} / \mathrm{ml}$} & \multicolumn{2}{|c|}{ [protein]: $5.0 \mathrm{mg} / \mathrm{ml}$} \\
\hline & $\mathrm{k}_{\mathrm{g}} \times 10^{3}\left(\mathrm{ml}^{-1} \cdot \mathrm{s}^{-1}\right)$ & $k_{d} \times 10^{4}\left(\mathrm{ml}^{-1} \cdot \mathrm{s}^{-1}\right)$ & $k_{\mathrm{g}} \times 10^{3}\left(\mathrm{ml}^{-1} \cdot \mathrm{s}^{-1}\right)$ & $k_{d} \times 10^{4}\left(\mathrm{ml}^{-1} \cdot \mathrm{s}^{-1}\right)$ & $k_{\mathrm{g}} \times 10^{3}\left(\mathrm{ml}^{-1} \cdot \mathrm{s}^{-1}\right)$ & $\mathrm{k}_{\mathrm{d}} \times 10^{4}\left(\mathrm{ml}^{-1} \cdot \mathrm{s}^{-1}\right)$ \\
\hline HT HDeg $0 \%$ & $10 \pm 1^{b}$ & $0.005 \pm 0.001^{\mathrm{b}}$ & $6.2 \pm 0.9^{c}$ & $0.005 \pm 0.001^{\mathrm{b}}$ & $3.0 \pm 0.2^{\mathrm{a}}$ & $0.005 \pm 0.001^{\mathrm{b}}$ \\
\hline HT HDeg $1.8 \%$ & $12 \pm 3^{b}$ & $0.005 \pm 0.001^{\mathrm{b}}$ & $5.1 \pm 0.5^{\mathrm{c}}$ & $0.005 \pm 0.001^{\mathrm{b}}$ & $3.2 \pm 0.3^{\mathrm{a}}$ & $0.005 \pm 0.001^{\mathrm{b}}$ \\
\hline HT HDeg $2.5 \%$ & $14 \pm 2^{b}$ & $0.005 \pm 0.001^{\mathrm{b}}$ & $5.5 \pm 0.9^{c}$ & $0.005 \pm 0.001^{\mathrm{b}}$ & $3.3 \pm 0.9^{\mathrm{a}}$ & $0.005 \pm 0.001^{\mathrm{b}}$ \\
\hline HT HDeg $6.0 \%$ & $37 \pm 7^{d}$ & $0.005 \pm 0.001^{\mathrm{b}}$ & $27 \pm 5^{d}$ & $0.005 \pm 0.001^{\mathrm{b}}$ & $8.0 \pm 0.9^{c}$ & $0.005 \pm 0.001^{\mathrm{b}}$ \\
\hline HpH HDeg 0\% & $3.4 \pm 0.6^{\mathrm{a}}$ & $9 \pm 2^{\mathrm{a}}$ & $3.8 \pm 0.8^{\mathrm{a}}$ & $5 \pm 1^{\mathrm{a}}$ & $2.7 \pm 0.3^{\mathrm{a}}$ & $5 \pm 1^{\mathrm{a}}$ \\
\hline HpH HDeg $2.5 \%$ & $2.5 \pm 0.1^{\mathrm{a}}$ & $7 \pm 2^{a}$ & $3.0 \pm 0.6^{\mathrm{a}}$ & $5 \pm 1^{\mathrm{a}}$ & $2.8 \pm 0.4^{\mathrm{a}}$ & $5 \pm 1^{a}$ \\
\hline HpH HDeg $6.0 \%$ & $3.5 \pm 0.4^{\mathrm{a}}$ & $7 \pm 2^{a}$ & $2.8 \pm 0.2^{\mathrm{a}}$ & $5 \pm 1^{\mathrm{a}}$ & $2.9 \pm 0.6^{\mathrm{a}}$ & $5 \pm 1^{\mathrm{a}}$ \\
\hline
\end{tabular}

Mean values of triplicate measurements are shown

Mean values identified by the same letter do not differ significantly $(\alpha=0.05)$

Disproportionation may be inhibited or retarded by a sufficiently thick layer of interfacial film as to resist the passage of gas [35], $\mathrm{HpH}$ foams thus being expected to show a greater resistance against disproportionation. The fact that HT foams showed a greater resistance to disproportionation, however, results from a strong dependence of such resistance on the bubble size of a particular foam, the latter being greater for HTs. However, as the increase in protein concentration led to the formation of increasingly resistant film, the above reported difference between hydrolysate types was lessened.

\subsubsection{Volumetric Proportions of Gravitational Liquid Drainage and Ostwald's Ripening}

In addition to the study of the above kinetic constants, the contributions of gravitational liquid drainage $\left(\mathrm{V}_{\mathrm{g}}\right)$ and disproportionation $\left(\mathrm{V}_{\mathrm{d}}\right)$ to the total drained liquid volume were analyzed according to variations in the study parameters (Table 4).

The proportion of liquid drained by gravitational drainage was significantly higher -at ratios no smaller than 0.80 - than that due to disproportionation for all the assayed foams. The 
$\mathrm{V}_{\mathrm{g}}$ value was found not to depend significantly on protein concentration for foams prepared with $\mathrm{HpHs}$ (Table 4). In contrast, in foams prepared with HTs, $\mathrm{V}_{\mathrm{g}}$ was found to increase with increasing protein concentration (Table 4), unlike $\mathrm{k}_{\mathrm{g}}$ decreasing with increasing protein concentration (Table 3 ).
Foams prepared with HTs at a protein concentration of 5 $\mathrm{mg} / \mathrm{ml}$ showed $\mathrm{V}_{\mathrm{g}}$ values in the range of 0.98 and 1.00 , the contribution of disproportionation to the total volume of drained liquid being negligible or nil (Table 4).

Table 4. $V_{g}$ and $V_{d}$ in foams prepared using SPIHs at $\mathrm{pH} 8.0$ for different protein concentrations

\begin{tabular}{|c|c|c|c|c|c|c|}
\hline \multirow{2}{*}{ SPIH } & \multicolumn{2}{|c|}{ [protein]: $1.0 \mathrm{mg} / \mathrm{ml}$} & \multicolumn{2}{|c|}{ [protein]: $2.0 \mathrm{mg} / \mathrm{ml}$} & \multicolumn{2}{|c|}{ [protein]: $5.0 \mathrm{mg} / \mathrm{ml}$} \\
\hline & $\mathbf{V}_{g}(\mathbf{m l})$ & $\mathrm{V}_{d}(\mathbf{m l})$ & $\mathbf{V}_{g}(\mathbf{m l})$ & $\mathbf{V}_{d}(\mathbf{m l})$ & $\mathbf{V}_{g}(\mathbf{m l})$ & $\mathbf{V}_{d}(\mathbf{m l})$ \\
\hline HT HDeg $0 \%$ & $0.90 \pm 0.02^{\mathrm{a}}$ & $0.10 \pm 0.01^{b}$ & $0.99 \pm 0.02^{\mathrm{c}}$ & $0.01 \pm 0.01^{\mathrm{d}}$ & $1.00 \pm 0.00^{\mathrm{c}}$ & 0.00 \\
\hline HT HDeg $1.8 \%$ & $0.89 \pm 0.02^{\mathrm{a}}$ & $0.11 \pm 0.01^{b}$ & $0.97 \pm 0.02^{\mathrm{c}}$ & $0.03 \pm 0.01^{\mathrm{d}}$ & $1.00 \pm 0.00^{c}$ & 0.00 \\
\hline HT HDeg $2.5 \%$ & $0.92 \pm 0.02^{\mathrm{a}}$ & $0.08 \pm 0.01^{\mathrm{b}}$ & $0.94 \pm 0.03^{\text {a.c }}$ & $0.06 \pm 0.01^{\text {b.d }}$ & $0.98 \pm 0.01^{\mathrm{c}}$ & $0.02 \pm 0.01^{\mathrm{d}}$ \\
\hline HT HDeg $6.0 \%$ & $0.90 \pm 0.02^{\mathrm{a}}$ & $0.10 \pm 0.01^{\mathrm{b}}$ & $0.95 \pm 0.02^{c}$ & $0.05 \pm 0.01^{\mathrm{d}}$ & $0.99 \pm 0.01^{\mathrm{c}}$ & $0.01 \pm 0.01^{\mathrm{d}}$ \\
\hline HpH HDeg 0\% & $0.90 \pm 0.02^{\mathrm{a}}$ & $0.10 \pm 0.01^{\mathrm{b}}$ & $0.87 \pm 0.02^{\mathrm{a}}$ & $0.13 \pm 0.01^{\mathrm{b}}$ & $0.84 \pm 0.02^{\mathrm{a}}$ & $0.16 \pm 0.01^{\mathrm{b}}$ \\
\hline HpH HDeg $2.5 \%$ & $0.85 \pm 0.02^{\mathrm{a}}$ & $0.15 \pm 0.01^{\mathrm{b}}$ & $0.86 \pm 0.02^{\mathrm{a}}$ & $0.14 \pm 0.01^{b}$ & $0.86 \pm 0.02^{\mathrm{a}}$ & $0.14 \pm 0.01^{b}$ \\
\hline HpH HDeg 6.0\% & $0.89 \pm 0.02^{\mathrm{a}}$ & $0.11 \pm 0.01^{\mathrm{b}}$ & $0.88 \pm 0.02^{\mathrm{a}}$ & $0.12 \pm 0.01 b^{b}$ & $0.84 \pm 0.02^{\mathrm{a}}$ & $0.16 \pm 0.01^{\mathrm{b}}$ \\
\hline
\end{tabular}

Mean values of triplicate measurements are shown

Mean values identified by the same letter do not differ in significant amounts $(\alpha=0.05)$

The relative amounts of liquid drained by gravitational drainage and disproportionation respectively do not only depend on the bubble size but also on the resistance of the protein film at the interface. In conditions as used for the above-described assays, liquid drainage was predominantly driven by gravitation rather than disproportionation.

Worth noting is the mutual dependence between $V_{g}$ and $V_{d}$ values, unlike the case of $\mathrm{k}_{\mathrm{g}}$ and $\mathrm{k}_{\mathrm{d}}$, as the former are expressed as proportions.

Unlike $k_{g}, k_{d}$ values were found to depend on the protein concentration in aqueous dissolution as used for the abovedescribed assays, resulting in a reduction of $k_{d}$ with increasing concentration, and, in turn, a lesser extent of drainage due to disproportionation, and thus a higher proportion of the total drained liquid volume due to gravitational drainage (Table 3). The rate of gravitational drainage may be described by means of the Reynolds equation [36]:

$$
\mathrm{V}=-\mathrm{dh} / \mathrm{dt}=\left(2 \mathrm{~h}^{3} / 3 \mu \mathrm{R}^{2}\right) \Delta \mathrm{P}
$$

where $\mathrm{h}$ is the thickness of the lamella, $\mathrm{t}$ time, $\mu$ the dynamic viscosity, $\mathrm{R}$ the bubble radius and $\Delta \mathrm{P}$ the pressure gradient according to Laplace's law. The rate of gravitational drainage clearly decreases with decreasing thickness of the lamella. A similar prediction may be made for drainage through Plateau borders [34]. The volume of liquid drained by gravitation will approach a constant value with time; a value which was found not to vary significantly with increasing protein concentration, consistent with insignificant differences found in $\mathrm{k}_{\mathrm{g}}$ or $\mathrm{V}_{\max }$ values for different concentration levels. Therefore, the decrease in $\mathrm{k}_{\mathrm{d}}$ did not lead to a reduction of the volume of drained liquid due to disproportionation, yet, it did result in an increase of the time required to attain complete drainage of liquid incorporated in the foam.

Whereas the difference in $\mathrm{k}_{\mathrm{g}}$ values between $\mathrm{HT}$ and $\mathrm{HpH}$ foams lessened with increasing protein concentration, $\mathrm{V}_{g}$ values for HT foams were significantly higher than for $\mathrm{HpH}$ foams at protein concentrations of $2 \mathrm{mg} / \mathrm{ml}$ and $5 \mathrm{mg} / \mathrm{ml}$. In HT foams, while an increase in protein concentration led to retardation in the rates of both gravitational drainage and disproportionation processes, the latter was found to occur to a less significant extent.

\section{Conclusions}

According to the results reported here, a low hydrolysis degree (HDeg 1.8 and 2.5\%) did not result in the enhancement of the foaming properties of hydrolysates obtained by freezing. For hydrolysates of this type, only a high hydrolysis degree (HT of HDeg 6\%) affected the foaming properties adversely. The loss of foaming capacity of HT of HDeg $6 \%$ was due to a greater bubble size and a lower $\mathrm{V}_{\max }$ value, and the lower stability found for foams of this hydrolysate was reflected in a higher $\mathrm{k}_{\mathrm{g}}$ value.

The adverse effect of an increasing hydrolysis degree on the behaviour of foams prepared with HTs was attributed to a reduction in polypeptide molecular size, leading to the formation of a film layer lacking adequate viscoelasticity and cohesion. Such adverse behaviour may be ascribed to the effect of hydrolysis on $\beta$-conglycinin -rather than on glycinin. Whereas improved foaming properties may be attributed to glycinin, an excess number of small-sized polypeptides particularly those resulting from the hydrolysis of $\beta$ conglycinin- were found to compete with the larger-sized proteins for adsorption at the interface, thus leading to the formation of less cohesive, viscoelastic and resistant film.

$\mathrm{HpHs}$ showed improved foaming properties with respect to the untreated isolates, consistently with smaller-sized bubbles and greater $v_{i}, \mathrm{~V}_{\text {max }}$ and $\mathrm{k}_{\mathrm{g}}$ values found for foams prepared with the former. The positive effect of $\mathrm{pH}$ treatment on interfacial properties was attributed to the dissociation and denaturation of soybean protein leading to favourable viscoelastic and cohesive properties of the film layer at the interface.

No adverse effect of a high hydrolysis degree (HDeg 6\%) 
was found on the foaming properties of hydrolysates subject to $\mathrm{pH}$ treatment. Whereas low-pH treatment leads to dissociation of $\beta$-conglycinin, a great extent of hydrolysis adversely affected the foaming properties of $\mathrm{HpHs}$ of HDeg $6 \%$. Therefore, the improvement of film properties leading to enhanced functional properties found for $\mathrm{HpHs}$ may be largely attributed to the dissociation of glycinin into subunits $\mathrm{AB}$ and to their denaturation.

\section{Acknowledgements}

Financial support was granted by CSIC (Comisión Sectorial de Investigación Científica) of Universidad de la República, PDT (Plan de Desarrollo Tecnológico) of the Ministry of Culture and Education (Grant S/C/BE/06/15) and PEDECIBA (Plan de Desarrollo de las Ciencias Básicas), Uruguay. Text translated by Chem. Eng. Eduardo Speranza.

\section{References}

[1] van Vliet, T.; Martin, A. H. \& Bos, M. A. (2002). Gelation and interfacial behaviour of vegetable proteins. Current Opininion in Colloid \& Interface Science. 7, 462 - 468.

[2] Damodaran, S. (2005). Protein stabilization of emulsions and foams. Journal of Food Science. 70, $54-66$.

[3] Schwenke, K. D. (2001). Reflections about the functional potential of legume proteins. A review. Nahrung. 45, 377-381.

[4] Were, L.; Hettiarachchy, N. S. \& Kalapathy, U. (1997). Modified Soy proteins with improved foaming and water hydration properties. Journal of Food Science. 62, 821-824.

[5] Wu, W.; Hettiarachchy, N. S. \& Qi, M. (1998). Hydrophobicity, solubility, and emulsifying properties of soy protein peptides prepared by papain modification and ultrafiltration. Journal of the American Oil of Chemists' Society. 75, 845-850.

[6] Petruccelli, S. \& Añón, M. C. (1994). The realtionship between the method of preparation and the structural and functional properties of soy protein isolates. Part I: Structural and hydration properties. Journal of Agriculture and Food Chemistry. 42, 2161-2169.

[7] Adler-Nissen, J. (1976). Enzymic hydrolysis of proteins for increased solubility. Journal of Agricultural and Food Chemistry. 24, 1090 - 1093.

[8] Cayot, P., \& Tainturier, G. (1997). The quantification of protein amino groups by the trinitrobenzenesulfonic acid method: a reexamination. Analytical Biochemistry. 249, 184200.

[9] Lowry, O. H.; Rosembroug, H. J.; Lewis, A. \& Randall, R. J. (1951). Protein measurement with the folin phenol reagent. Journal of Biological Chemistry. 193, 265-275.

[10] AOAC. (1975). Official methods of analysis. Washington: Association of Official Analytical Chemists.

[11] Hayakawa, S. \& Nakai, S. (1985). Relationships of hydrophobicity and net charge to the solubility of milk and soy proteins. Journal of Food Science. 50, 486-491.
[12] Kato, A. \& Nakai, S. (1980). Hydrophobicity determined by fluorescence probe method and its correlation with surface properties of proteins. Biochimica et Biophysica Acta. 624; 13-20.

[13] Petruccelli, S. \& Añón, M. C. (1995). Thermal aggregation of soy protein isolate. Journal Agriculture Food Chemistry. 43, 3035-3042.

[14] Panizzolo, L. A.; Mussio, L. E. y Añón, M. C. 2014. A kinetic model for describing the effect of proteins on the air-water interface tension. Journal of Food Science and Engineering. (in press).

[15] Loisel, W.; Guéguen, J. \& Popineau, Y. (1993). A new apparatus for analyzing foaming properties of proteins. In K. D. Schwenke, \& R. Mothes, Food Proteins. Structure and functionality (pp320-323). Weinheim: VCH.

[16] Wagner, J. R.; Sorgentini, D. A. \& Añón, M. C. (1996). Thermal and electrophoretic behavior, hydrophobity and some functional properties of acid-treatred soy isolates. Journal of Agricultural and Food Chemistry. 44, 1881-1889.

[17] Panizzolo, L. A.; Mussio, L. E. y Añón, M. C. (2012). A kinetic description for the destabilization process of protein foams. International Journal of Food Properties. 15 (1), 60-68.

[18] Molina Ortiz, S. E. (1997). Modificación enzimática de propiedades funcionales de aislados proteicos de soja. Tesis, Facultad de Ciencias Exactas, Universidad Nacional de La Plata, Argentina.

[19] Wagner, J. R. \& Añón, M. C. (1990). Influence of denaturation, hydrophobicity and sulfhidryl content on solubility and water absorbing capacity of soy protein isolate. Journal of Food Science. 50, 765-770

[20] Puppo, M. C. \& Añón, M. C. (1999). Soybean protein dispersions at acid $\mathrm{pH}$. Thermal and rheological properties. Journal of Food Science. 64, 50-56.

[21] Schwenke, K. D.; Staatz, A.; Dudek, S.; Krause, J. P. \& Noack, J. (1995). Legumin-T from faba bean legumin: isolation, partial characterization and surface functional properties. Nahrung. 39, 193-.202.

[22] Koshiyama, I. (1972). Comparison of acid induced conformation changes between $7 \mathrm{~S}$ and $11 \mathrm{~S}$ globulin in soybean seeds. Journal of the Science of Food and Agriculture. 23, 853-859.

[23] Martin, A. H.; Bos, M. A. \& van Vliet, T. (2002). Interfacial rheological properties and conformational aspects of soy glycinin at the air_water interface. Food Hydrocolloids. 16, 63-71.

[24] Garofalakis, G. \& Murray, B. S. (2001). Dilatational rheology and foaming properties of sucrose monoesters in the presence of b-lactoglobulin. Colloids and Surfaces B Biointerfaces. 21, 3-17.

[25] Damodaran, S. (1996). Amino acids, peptides, and proteins. In O. R. Fennema, Food Chemistry (pp 321-429). New York: Marcel Dekker.

[26] Graham, D. E. \& Phillips, M. C. (1976). The conformation of proteins at the air-water interface and their role in stabilizing foams. In Foam, editado por Akers, R. J. Academic Press, New York. 237-255. 
[27] Phillips, L. G. (1981). Protein conformation at liquid interfaces and its role in stabilizing emulsions and foams. Food Technology. 35, 50-57.

[28] Kinsella, J. E. (1981). Relationship between structure and functional properties of food proteins. In P. F. Fox, \& J. J. Condon. Food Proteins. London: Applied Science Publishers.

[29] Cheftel, J. C., Cuq J. L., \& Lorient, D. (1985). Aminoacids, Peptides and Proteins. In O. R. Fennema, Food Chemistry (pp 245-369). New York: Marcel Dekker.

[30] Damodaran, S. (1997). Protein-stabilized foams and emulsions. In S. Damodaran, \& A. Paraf. Food proteins and their applications (pp 57-110). New York: Marcel Dekker,

[31] Hill, S. E. (1998). Emulsions and foams. In S. E. Hill, D. A. Ledward, \& J. R. Mitchell. Fuctional properties of food macromolecules (pp 302-334). Maryland: Aspen Publishers, Inc.

[32] Sorgentini, D. A.; Wagner, J. R. \& Añón, M. C. (1995). Effects of thermal treatment of soy protein isolate on the characteristics and structure: function relationship of soluble and insoluble fractions. Journal of Agriculture and Food Chemistry. 43, 2471-2479.

[33] Walstra, P. (1996). Dispersed systems: basic considerations. In O. R. Fennema, Food Chemistry (pp 95-155). New York: Marcel Dekker.

[34] Halling, P.J. (1981). Protein stabilized foam and emulsions. CRC Critical Reviews in Food Science and Nutrition. 15: 155203.

[35] Salager, J. L.; Andérez, J. M. \& Forgiarini, A. (2003). Influencia de la formulación sobre las espumas. Cuaderno Firp 263-A. Universidad de Los Andes, Mérida, Venezuela.

[36] Manev, E. D.; Sazdanova, S. V. \& Wasan, D. T. (1984). Emulsion and foam stability: the effect of film size on film drainage, Journal of Colloid and Interface Science. 97, 591594. 